\title{
Towards an effective poliovirus laboratory containment strategy in Nigeria
}

\author{
Johnson Muluh Ticha ${ }^{{ }^{*}}$, Kolawole Olatunji Matthew ${ }^{4}$, Abdullahi Walla Hamisu', Braka Fiona', Pascal Mkanda², \\ Peter Nsubuga ${ }^{6}$, Eberto Tesfaye ${ }^{1}$, Kehinde Craig ${ }^{1}$, Etsano Andrew ${ }^{3}$, Obi Emelife ${ }^{3}$, Faisal Shuaib ${ }^{4}$, \\ Akinkugbe Folasade ${ }^{4}$, Johnson Adeniji ${ }^{4}$, Usman Adamu ${ }^{4}$, Mohammed Dallatu', Geoffrey Oyeyinka ${ }^{4}$, Holly Brown ${ }^{4}$, \\ Nwakasik Nnamah ${ }^{4}$, Joseph Okwori ${ }^{4}$, Chukwuike Chinedu ${ }^{4}$, Ibikunle Anibijuwon ${ }^{4}$, Adewumi Olubusuyi ${ }^{4}$, \\ Donbraye Emmanuel ${ }^{4}$, Murtala Bagana ${ }^{4}$, Marycelin Baba ${ }^{5}$, Gumede Nicksy², Richard Banda', Sisay G. Tegegne?, \\ Ajiboye Oyetunji ${ }^{1}$, Ousmane Diop ${ }^{7}$, O. Tomori ${ }^{8}$ and Rui G. Vaz ${ }^{1}$
}

\begin{abstract}
Background: The Global Commission for the Certification of the Eradication of Poliomyelitis will declare the world free of wild poliovirus transmission when no wild virus has been found in at least 3 consecutive years, and all laboratories possessing wild poliovirus materials have adopted appropriate measures of containment. Nigeria has made progress towards poliomyelitis eradication with the latest reported WPV type 1 on 21 Aug 2016 after 2 years without any case. This milestone achievement was followed by an inventory of biomedical laboratories completed in November 2015 with the destruction of all identified infectious materials. This paper seeks to describe the poliovirus laboratory containment process in Nigeria on which an effective containment system has been built to minimize the risk of virus re-introduction into the population from the laboratories.
\end{abstract}

Methods: A national survey of all biomedical facilities, as well as an inventory of laboratories from various sectors, was conducted from June-November 2015. National Task Force (NTF) members and staff working on polio administered an on-site questionnaire in each facility. Laboratory personnel were sensitized with all un-needed materials destroyed by autoclaving and incineration. All stakeholders were also sensitized to continue the destruction of such materials as a requirement for phase one activities.

Results: A total of 20,638 biomedical facilities were surveyed with 9575 having laboratories. Thirty laboratories were found to contain poliovirus or potentially infectious materials. The 30 laboratories belonged to the ministries of health, education, defence and private organizations.

Conclusions: This article is amongst the first in Africa that relates poliovirus laboratory containment in the context of the tOPV-bOPV switch in alignment with the Global Action Plan III. All identified infectious materials were destroyed and personnel trained to continue to destroy subsequent materials, a process that needs meticulous monitoring to mitigate the risk of poliovirus re-introduction to the population.

Keywords: Laboratory, Containment, Poliovirus, Biosafety, Potentially infectious material, Survey, Inventory, Eradication

\footnotetext{
* Correspondence: tichaj@who.int

${ }^{1}$ World Health Organization, Country Representative Office, Abuja, Nigeria

Full list of author information is available at the end of the article
}

(c) The Author(s). 2018 Open Access This article is distributed under the terms of the Creative Commons Attribution 4.0 International License (http://creativecommons.org/licenses/by/4.0/), which permits unrestricted use, distribution, and reproduction in any medium, provided you give appropriate credit to the original author(s) and the source, provide a link to the Creative Commons license, and indicate if changes were made. The Creative Commons Public Domain Dedication waiver (http://creativecommons.org/publicdomain/zero/1.0/) applies to the data made available in this article, unless otherwise stated. 


\section{Background}

In May 1999, the World Health Assembly urged Member States to begin the process leading to laboratory containment of the wild poliovirus (WPV). On 25th May 2015, all World Health Organization (WHO) member countries endorsed the World Health Assembly resolution 68.3 on full implementation of the Polio Eradication and Endgame Strategic Plan 2013-2018 and with it the third Global Action Plan to minimize poliovirus facility-associated risk (GAP III) [1]. The Endgame Plan sets the goal of a polio-free world by 2018 [2]. One of the ways to achieving this is through the implementation of safe handling and containment measures for polioviruses to minimize the risks of the facility-associated reintroduction of the virus into the polio-free community [3]. In September 2015, the global commission for the certification of poliomyelitis (GCC) declared that wild poliovirus type 2 had been eradicated [4]. Polio outbreaks following certification might be caused by either wild or vaccine-derived poliovirus (VDPV), they could originate from various sources, and they could occur anywhere [5].

In 2014, Wolff et al. reported that containment phase 1 activities were completed in 154 (79\%) of 194 WHO Member States, including all countries and areas of the polio-free regions and most polio-free countries in the remaining three regions [6]. This progress, particularly in several large industrialized countries, showed that wild poliovirus containment is operationally feasible [7].

The GCC will declare the world free of wild poliovirus transmission when no wild virus has been found in at least 3 consecutive years, and all laboratories possessing wild poliovirus materials have adopted appropriate measures of laboratory containment [8].

There is a paucity of data on the African continent or sub-region on the containment of WPV and potentially infectious materials. However, despite this, containment process was concluded in Zambia in 2012 with a survey of $>170$ biomedical facilities ending up with one laboratory (i.e., the Lusaka University Teaching Hospital) having stocks of wild poliovirus and potentially infectious materials [9]. In 2008, in Sudan, 26 (6.1\%) laboratories out of the 422 surveyed were found having poliovirus or potentially infectious materials [10]. By 2016 Nigeria had made progress towards poliomyelitis eradication with no case reported in 2 years, however between July and August 2016, four WPV1 cases were reported. These cases were restricted to Borno state in the northeast of the country which was facing security challenges.

This article seeks to showcase keys achievements of phase 1a poliovirus laboratory containment process in Nigeria, a foundation for an effective poliovirus containment system in a country without an essential facility.

\section{Methods}

Phase 1a containment activities were carried out based on WHO guidelines.

\section{Creation of National Task Force (NTF) and work plan}

Phase 1a containment activities commenced with the institution of the NTF in January 2015 by the Government. Six consultant virologists (one per geopolitical zone) were engaged from June-November 2015 for this activity. Both NTF and the consultants had a capacity building workshop in May 2015 (before the commencement of survey). The NTF elaborated a 6 months' work plan (June-November 2015).

\section{National stakeholder's sensitization}

Apart from building the capacity of the NTF and consultants, a broad spectrum of stakeholders were sensitized in May 2015 on the concept and logistics of the national survey and inventory. Participants to the forum were drawn from several ministerial departments and government agencies amongst which were the National Agency for Food and Drug Administration and Control (NAFDAC) and the Medical Laboratory Council of Nigeria. Introductory letters on containment requirements were provided to stakeholders and copies were sent to various biomedical facilities for compliance with the process.

Establishment of a preliminary list of biomedical facilities At the commencement of survey in June 2015, a list of existing biomedical facilities in the country was provided by the Medical Laboratory Council of Nigeria, the Nigeria Medical Association, the Federal Ministries of Health, Defense and Agriculture.

\section{Pre-testing of survey questionnaire}

The WHO generic questionnaire for poliovirus containment was adopted and pre-tested in one state of each of the six geo-political zones in May 2015 before the commencement of the survey in June 2015.

\section{Administration of questionnaires}

The questionnaires were physically taken to all biomedical facilities in the country by the six consultants and supported by personnel working on the polio eradication activities. NTF members also conducted a survey of low-risk facilities during supervisory field visits.

Questionnaires were completed on site by the laboratory heads in the presence of the consultants. In rare occasions, the consultants had to come back some other time to collect the completed forms. An onsite inventory was carried out for facilities found with poliovirus infectious or potentially infectious materials. 
These questionnaires were directed towards the identification of sample types, their sources, quantification, storage conditions including temperature, date of collection and methods of destruction once not more needed in the laboratory.

\section{Data management}

Completed questionnaires for both survey and inventory were transmitted to $\mathrm{WHO}$, and all the data were entered into an MS Access computer database for analysis and sharing with government and partners every week. All data generated from the study were checked manually for errors in filling responses, in some cases more information was requested, or the consultants returned to the facility for onsite review. Descriptive statistics such as mean, frequency, standard deviation, percentages and graphs were used to analyze the results. The data were analyzed using Epi Info version 3.5.3 (US Centers for Disease Control and Prevention) and the Statistical Program for the Social Sciences (SPSS 21) computer software packages.

\section{Supervision and coordination of containment process}

Physical visits were made by the NTF members to supervise the containment process. They visited all laboratories in tertiary institutions as well as other laboratories identified with poliovirus or potentially infectious materials. Each NTF field visit was followed by meetings with the consultants to propose solutions to identified difficulties to the process.

\section{Laboratory inventory}

The national inventory of laboratories having poliovirus infectious or potentially infectious materials was compiled indicating name of the laboratory, organization or ministerial department. The type of material identified, the quantity of material in store, storage temperature, the level of risk of the laboratory and the contact information of head of the facility was recorded.

\section{Destruction of poliovirus infectious or potentially infectious materials}

The identified poliovirus or potentially infectious materials in all biomedical facilities were destroyed using the best standard practices of autoclaving and incineration. The destruction was implemented through a directive from the Federal Government of Nigeria to all heads of the identified laboratories. The destruction process was supervised and monitored by NTF members.

\section{Report of phase 1a activities}

A report on the processes and findings of laboratory containment activities was written and forwarded to the Africa Regional Commission for the Certification of Poliomyelitis Eradication on 31st December 2015 through WHO country office as was required.

\section{Post-phase 1a laboratory containment activities}

An enlarged stakeholder meeting (comprising mostly heads of the laboratories with an inventory of materials) was organized by the government. The meeting served as feedback on phase one containment activities as well as to train them on standard operating procedures (SOPs) for safe handling and destruction of subsequent polioviruses or potentially infectious materials in the laboratories henceforth. The forum was also charged to update the list of laboratories annually to be coordinated by the Medical Laboratory Council of Nigeria for which the NTF was to regularly visit and ensure compliance with biosafety particularly the immediate destruction of polioviruses or potentially infectious materials.

\section{Destruction of type 2 poliovirus after the trivalent Oral polio vaccine to bivalent Oral polio vaccine (tOPV to bOPV) switch}

From 5th Feb 2016 to 5th July 2016, all type 2 poliovirus in both national polio laboratories in Ibadan and Maiduguri were destroyed through autoclaving and incineration.

\section{Results}

Between June and November 2015, NTF conducted phase 1a poliovirus containment activities in all 36 states and the Federal Capital Territory. At the commencement of this survey in June 2015, a list of 16,722 biomedical facilities was provided by governmental and non-governmental institutions. At the end of the survey in November 2015, a total of 7340 (43.9\%) of these 16, 722 facilities were seen to have closed down. Similarly, it was noted that 12,906 (77.1\%) facilities were surveyed that were not on the initial list. Thus in November 2015, a total of 20,638 biomedical facilities were surveyed these including those on the initial list as well as new facilities discovered in the field. A total of 9575 (46.4\%) of the 20,638 facilities surveyed had an inventory for poliovirus or potentially infectious materials (Table 1 ).

A total of $4637(48.6 \%)$ of 9575 laboratories surveyed were validated both by NTF and consultants. The response rate for the onsite administration of the questionnaires was $99 \%$ because 36 of the 9,575 laboratories declined (initially) participation in the survey. A total of $30(0.3 \%)$ of the 9575 laboratories surveyed were in possession of poliovirus infectious or potentially infectious materials. These 30 laboratories belonged to various Ministries as follows; Health 15 (50\%), Education 11 (36.7\%), Defence 1 (3.3\%), Private Organizations $3(10 \%)$. Most of these 30 laboratories $(26.6 \%)$ were found concentrated in 
Table 1 Distribution of the number of biomedical facilities surveyed and identified laboratories by geopolitical zones June-November 2015

\begin{tabular}{llllllll}
\hline $\begin{array}{l}\text { Geo-political } \\
\text { zone }\end{array}$ & $\begin{array}{l}\text { No of Facilities on } \\
\text { initial official list }\end{array}$ & $\begin{array}{l}\text { No of Facilities on } \\
\text { initial official list } \\
\text { found closed down }\end{array}$ & $\begin{array}{l}\text { No of Facilities that } \\
\text { were not on official } \\
\text { list but surveyed }\end{array}$ & $\begin{array}{l}\text { Total No of Facilities } \\
\text { in furveyed } \\
\text { surve }\end{array}$ & $\begin{array}{l}\text { No of Facilities } \\
\text { with labs }\end{array}$ & $\begin{array}{l}\text { No of Facilities } \\
\text { without labs }\end{array}$ & $\begin{array}{l}\text { Total number of } \\
\text { labs surveyed }\end{array}$ \\
\hline $\begin{array}{l}\text { North } \\
\text { Central }\end{array}$ & 2452 & 1269 & 2852 & 4115 & 2512 & 1603 & 2512 \\
North East & 902 & 156 & 192 & 850 & 508 & 342 & 508 \\
North West & 1578 & 32 & 2126 & 3928 & 1044 & 2884 & 1044 \\
South East & 3223 & 1194 & 2085 & 3375 & 2327 & 1048 & 2327 \\
South West & 5610 & 2960 & 3159 & 4652 & 1777 & 2875 & 1777 \\
South South & 2957 & 1729 & 2492 & 3718 & 1407 & 2311 & 1407 \\
Total & 16,722 & 7340 & 12,906 & 20,638 & 9575 & 11,063 & 9575 \\
\hline
\end{tabular}

the North Central zone (Table 2) compared with the other five zones.

A total of 189 (2\%), 1946 (20.3\%) and 7440 (77.3\%) of the 9575 laboratories surveyed were classified as high, medium, and low risk respectively. These high-risk laboratories were mostly found in the South-East zone of the country (67/189, or $35.4 \%)$. A total of $6(20 \%)$ of the 30 laboratories with inventory had Biosafety Level-2 (BSL-2) standards. These included the National Influenza Laboratory in Abuja, the WHO national polio laboratories in Ibadan and Maiduguri, Lagos University Teaching Hospital, University of Nigeria Enugu (bacteriology unit) and the University of Nigeria, Enugu (Nigeria Centre for Disease Control) (Table 3).

Among the infectious materials found in the laboratories; were 11,291 stools samples located in 16 laboratories, 15,801 throat swab samples seen in 3 laboratories and 5221 stool suspensions in 1 laboratory.

The two most common samples found in the laboratories were stool (in 60\%) and blood (in 16.7\%) of laboratories. All of these infectious materials were destroyed during the survey under the supervision of the NTF members and consultants (Table 3).
As per WHO guidelines on containment, the 4th of February 2016 was the dateline set for all countries in the Africa region to destroy all poliovirus or potentially infectious materials that accumulated after the ones destroyed during phase 1a exercise. Thus, 646 VDPV2 and 3256 Sabin 2 from AFP stools were destroyed in both Ibadan and Maiduguri polio laboratories. Secondly, 775 mixtures of Sabin2 and VDPV2 from sewage water were destroyed in Ibadan laboratory on the same day. (Table 4).

In alignment with the WHO containment guidelines, Nigeria had to continue to destroy all poliovirus or potentially infectious materials or transfer them to an essential facility with BSL-3 for polio. Nigeria has no such essential facility and thus the only option was to destroy it's infectious or potentially infectious materials (Tables 4 and 5).

\section{Discussion}

We found that $30(0.3 \%)$ of laboratories in Nigeria had poliovirus or potentially infectious materials. Six (20\%) of the 30 laboratories had biosafety level-2 standards for polio. In 2004, Sneyers et al. in Belgium found poliovirus or potentially infectious materials in $8(1.9 \%)$ of the 411 facilities surveyed

Table 2 Ministerial departments of laboratories found with poliovirus or potentially infectious materials during phase 1 containment activities June-November 2015

\begin{tabular}{|c|c|c|c|c|c|c|}
\hline \multirow{2}{*}{$\begin{array}{l}\text { Geo-political } \\
\text { zone }\end{array}$} & \multirow{2}{*}{$\begin{array}{l}\text { Number of laboratories } \\
\text { with inventory }\end{array}$} & \multicolumn{4}{|c|}{ Ministerial Department of laboratories with inventory } & \multirow[t]{2}{*}{ Total } \\
\hline & & $\begin{array}{l}\text { Ministry of } \\
\text { Health }\end{array}$ & $\begin{array}{l}\text { Private } \\
\text { Organization }\end{array}$ & $\begin{array}{l}\text { Ministry of } \\
\text { Education }\end{array}$ & $\begin{array}{l}\text { Ministry of } \\
\text { Defense }\end{array}$ & \\
\hline North Central & 8 & 7 & 0 & 0 & 1 & 8 \\
\hline North East & 1 & 0 & 0 & 1 & 0 & 1 \\
\hline North West & 6 & 3 & 0 & 3 & 0 & 6 \\
\hline South East & 4 & 3 & 1 & 0 & 0 & 4 \\
\hline South West & 6 & 1 & 1 & 4 & 0 & 6 \\
\hline South South & 5 & 1 & 1 & 3 & 0 & 5 \\
\hline Total & 30 & 15 & 3 & 11 & 1 & 30 \\
\hline
\end{tabular}


Table 3 Types and quantities of various polioviruses and or potentially infectious materials identified in 30 laboratories during inventory from June-November 2015 in Nigeria

\begin{tabular}{|c|c|c|c|c|}
\hline Name of Laboratories & Type of sample & Quantity & $\begin{array}{l}\text { Period of } \\
\text { Collection }\end{array}$ & $\begin{array}{l}\text { Storage } \\
\text { Temperature }\left({ }^{\circ} \mathrm{C}\right)\end{array}$ \\
\hline Modesty Med. Laboratory, Owerri, Imo & Stool & 5 & $20 / 04 / 15$ & 2 \\
\hline${ }^{a}$ N.C.D.C. Reference Laboratory, Enugu & Stool & 2226 & 2010-2015 & -60 \\
\hline $\begin{array}{l}\text { aBacteriology Unit, University of Nigeria } \\
\text { Teaching Hospital Enugu }\end{array}$ & Cerebrospinal fluid & 400 & $01 / 01 / 12$ & -60 \\
\hline IMSUTH Microbiology Lab - Orlu, IMO & Stool & 8 & 09/01/15 & 2 to 8 \\
\hline $\begin{array}{l}\text { aCentral Research Laboratory, College of } \\
\text { Medicine, } \\
\text { Lagos University Teaching Hospital, } \\
\text { Idi-Araba, LAGOS }\end{array}$ & Stool & 110 & $2011-2012$ & -20 \\
\hline $\begin{array}{l}\text { N C D C Molecular Laboratory, Amino } \\
\text { Kano Teaching Hospital, Kano }\end{array}$ & Stool & 100 & 19/06/15 & -60 \\
\hline $\begin{array}{l}\text { Public health \&Diagnostic Institute North } \\
\text { West University, KANO }\end{array}$ & Stool & 20 & $10 / 02 / 15$ & -32 \\
\hline $\begin{array}{l}\text { Medical Microbiology Ahmadu Bello } \\
\text { University Teaching Hospital Shika Zaria, } \\
\text { Kaduna }\end{array}$ & Stool & 5 & 10/06/15 & -20 \\
\hline $\begin{array}{l}\text { Medical Department Barau Dikko Teaching } \\
\text { Hospital Kaduna, KADUNA }\end{array}$ & Sera & 1 & $17 / 06 / 15$ & -20 \\
\hline $\begin{array}{l}\text { University Health Services, ABU Zaria, } \\
\text { Kaduna }\end{array}$ & Stool & 10 & $01 / 02 / 15$ & 2 to 8 \\
\hline Garki Hospital Abuja Laboratory, FCT & Blood & 2 & 2015 & -20 \\
\hline Asokoro District Hospital Laboratory, FCT & Blood & 4 & 2015 & -20 \\
\hline $\begin{array}{l}\text { Defense Headquarters Medical Centre } \\
\text { Laboratory, Abuja, FCT }\end{array}$ & Sera & 100 & 2015 & room temperature \\
\hline $\begin{array}{l}\text { Micro-Biology Laboratory National Hospital, } \\
\text { Abuja, FCT }\end{array}$ & Stool & 14 & 2015 & 2 \\
\hline $\begin{array}{l}\text { Measles / Yellow Fever Laboratory, Abuja, } \\
\text { FCT }\end{array}$ & Sera & 100 & 2015 & -20 \\
\hline $\begin{array}{l}\text { aNational Influenza Reference Laboratory, } \\
\text { Asokoro District Hospital, Abuja, FCT }\end{array}$ & Throat swabs & 7894 & 2012 & -20 and -70 \\
\hline $\begin{array}{l}\text { University Of Abuja Teaching Hospital } \\
\text { Laboratory, FCT }\end{array}$ & Sera & 5 & 2015 & -20 \\
\hline $\begin{array}{l}\text { Rotavirus Laboratory, University of Ilorin, } \\
\text { Kwara }\end{array}$ & stool & 297 & 2013 & -80 \\
\hline $\begin{array}{l}\text { Landers Specialist Medical Laboratory, } \\
\text { Rivers }\end{array}$ & Stool & 1 & 2015 & 2 to 8 \\
\hline $\begin{array}{l}\text { Medical Laboratory Services, University of } \\
\text { Benin Teaching Hospital, EDO }\end{array}$ & Cerebrospinal fluid & 41 & 2015 & -80 \\
\hline $\begin{array}{l}\text { Microbiology Laboratory, University of } \\
\text { Port Harcourt) RIVERS }\end{array}$ & Water & 7 & Mar-Jul 2015 & 2 to 8 \\
\hline $\begin{array}{l}\text { Research Laboratory, Plant Science \& } \\
\text { Biotechnology Department, University of } \\
\text { Port Harcourt, Rivers }\end{array}$ & Water & 7 & 2015 & 2 to 8 \\
\hline Medical Microbiology Laboratory, RIVERS & Stool & 50 & 2015 & -20 \\
\hline $\begin{array}{l}\text { aWHO National Polio Laboratory, University } \\
\text { of Maiduguri Teaching Hospital, BORNO }\end{array}$ & Poliovirus Isolates - & 211 & & -20 \\
\hline Highland Specialist Hospital, Oyo & Throat Swap & 13 & June 2015 & 4 \\
\hline $\begin{array}{l}\text { Drug Research Unit, Institute for Advanced } \\
\text { Medical Research Ibadan, Oyo }\end{array}$ & Stool & 928 & June 2015 & -86 \\
\hline $\begin{array}{l}\text { Ibarapa Community \&Primary Healthcare } \\
\text { Program Laboratory, Oyo }\end{array}$ & Stool & 1 & April 2013 & 4 \\
\hline
\end{tabular}


Table 3 Types and quantities of various polioviruses and or potentially infectious materials identified in 30 laboratories during inventory from June-November 2015 in Nigeria (Continued)

\begin{tabular}{|c|c|c|c|c|}
\hline Name of Laboratories & Type of sample & Quantity & $\begin{array}{l}\text { Period of } \\
\text { Collection }\end{array}$ & $\begin{array}{l}\text { Storage } \\
\text { Temperature }\left({ }^{\circ} \mathrm{C}\right)\end{array}$ \\
\hline $\begin{array}{l}\text { Medical Microbiology, University College } \\
\text { Hospital, Ibadan Oyo }\end{array}$ & Stool & 400 & Feb 2014 & -20 \\
\hline $\begin{array}{l}\text { aWHO National Polio Laboratory, University } \\
\text { of Ibadan Teaching Hospital, OYO }\end{array}$ & $\begin{array}{l}\text { Stool } \\
\text { Stool suspensions } \\
\text { Non-Polio Enteroviruses } \\
\text { Sewage samples } \\
\text { Un-typed Sewage samples } \\
\text { Poliovirus isolates } \\
\text { Wild Poliovirus } \\
\text { Wild Poliovirus }\end{array}$ & $\begin{array}{l}6616 \\
5221 \\
5104 \\
1126 \\
400 \\
1140 \\
26 \\
1978 \\
730\end{array}$ & $\begin{array}{l}2015 \\
2015 \\
2011-2014 \\
2011-2014 \\
2011-2014 \\
2011-2014 \\
2011-2015 \\
2005-2014 \\
\text { Jan-Jul } 2015\end{array}$ & $\begin{array}{l}-20 \\
-20 \\
-20 \\
-40 \\
-20 \\
-20 \\
-20 \\
-20 \\
-20\end{array}$ \\
\hline Bacterial Zoonosis, Kaduna & Stool & 500 & 2015 & -20 \\
\hline
\end{tabular}

aLaboratories with BSL-2 facilities

and all of them (100\%) had BSL-2 [11]. Mpabalwamni et al. in 2012 reported that of the 170 biomedical facilities surveyed in Zambia, 24 (14.1\%) were found having both wild polioviruses as well as potentially infectious materials. Our findings are in accordance with similar studies; Wolff et al. in 2014 surveyed 227,209 biomedical facilities in 154 countries of the 194 WHO Member States and 532 $(0.2 \%)$ and identified 45 countries as retaining WPV or potentially infectious materials. These findings in Nigeria are again in agreement with those of Wolff et al. in which universities constituted the highest percentage of institutions retaining poliovirus materials. In Nigeria, all the poliovirus infectious or potentially infectious materials were all destroyed through autoclaving and incineration, this method was ideal to complete the phase 1a containment exercise since there wasn't an essential facility, atleast a BSL-3 Laboratory in-country or elsewhere in Africa by then.

We noted that apart from various types of polioviruses, the most common potentially infectious materials were stool samples $(11,291)$, throat samples $(15,801)$ and sera (200). As per GAPIII these materials were destroyed through autoclaving and incineration in various laboratories. Appropriate biosafety measures are crucial for the prevention of poliovirus infection of laboratory workers and subsequent transmission to the community. Destruction of these materials have also been reported by several authors in Sudan and Zambia.

We also found out that the two WHO-accredited polio laboratories in the universities of Ibadan and Maiduguri in addition to potentially infectious materials had large quantities of type 1 and type 3 wild poliovirus as well as type 2 polioviruses (Sabin2 and VDPV2) from both sewage and AFP samples. These type 2 polioviruses were destroyed as per GAPIII requirements for Phase 1a activities and in the context of the trivalent OPV to bivalent OPV switch that was effective on 18th April 2016 in Nigeria. WHO supported labs thus constitute a potential source of poliovirus and potentially infectious materials in Nigeria and elsewhere as cited in the Zambia study reported by Mpabalwani et al. in 2012 where large quantities were identified in the Lusuka WHO supported polio laboratory. Environmental surveillance will play a critical role in monitoring the effectiveness of the switch [12]. In this regards in New Zealand, Q Sue et al. reported that OPV strains did not persist for extended periods after a vaccine switch [13]. Environmental surveillance is now being conducted in 18 states in Nigeria thus keeping the country in a good position to be able to monitor the circulation of any Sabin 2.

Table 4 Quantities of Type 2 polioviruses destroyed on 4th February 2016 in the national polio laboratories

\begin{tabular}{lllll}
\hline & & Quantity destroyed in laboratories & \\
\hline Type 2 poliovirus & Source & lbadan & Maiduguri & Total \\
Sabin 2 & Sewage samples & 641 & 0 & 641 \\
Sabin 2 & AFP stools & 1750 & 1506 & 3256 \\
VDPV2 & Sewage samples & 135 & 0 & 135 \\
VDPV2 & AFP stools & 181 & 465 & 646 \\
Sabin 2+VDPV2 & Sewage samples & 775 & 0 & 775 \\
\hline
\end{tabular}


Table 5 Quantity of type 2 poliovirus destroyed between 5th February and 5th June 2016 in national polio laboratories

\begin{tabular}{lcccc}
\hline Polio lab & \multicolumn{2}{c}{ From AFP } & \multicolumn{2}{c}{ From ES } \\
\hline & VDPV2 & Sabin 2 & VDPV2 & Sabin2 \\
Maiduguri & 2 & 153 & $N^{2} / A^{a}$ & N/A \\
Ibadan & 0 & 29 & 1 & 51 \\
\hline
\end{tabular}

alaboratory doesn't test environmental samples. ES: Environmental sample

We also found that the Phase 1a laboratory survey offered the opportunity to establish a national list of 20,637 biomedical facilities as against 16,722 on the existing list. This updated list of biomedical facilities would serve as a useful baseline dataset for broader public health interventions beyond polio. This list of 20, 637 biomedical facilities was used during the April 2016 tOPV-bOPV switch in the country. Similarly in the Region of the Americas; six countries Argentina, Brazil, Chile, Colombia, Mexico and Peru established national registries that could be used beyond the goal of poliovirus containment. In Belgium, a list of 411 institutions was established for the survey with a respondent rate of $97.3 \%$ compared to the $99 \%$ rate in Nigeria. Nigeria conducted its survey using an on-site completion of the questionnaires contrarily to that in Belgium where in questionnaires were posted to various institutions. In Japan between 2004 and 2005, a total of 12,142 facilities were surveyed by the Ministry of Health, Labor and Welfare with a return rate of 99\% [14]. This large number of laboratories surveyed in Nigeria is comparable with that in many other countries.

We also found out that 2, 20.3 and $77.3 \%$ of the laboratories with poliovirus infectious or potentially infectious materials were classified as high, medium and low risk respectively for the presence of poliovirus.

We recognize limitations of our study. It cannot be stated with certainty that all biomedical facilities were included in the survey in a large nation like Nigeria. Secondly, even if all facilities were included, they might not have been correctly identified to quantify the type and amount of poliovirus or potentially infectious materials. Despite these limitations, our study was able to reach a high number of laboratories resulting in the destruction of both potentially infectious materials and type 2 polioviruses for which the destruction continues systematically in all laboratories as such ensuring appropriate poliovirus containment thus reducing the risk of reintroduction of poliovirus into the population.

\section{Conclusions}

The absolute laboratory containment of polioviruses or any virus, cannot be guaranteed, but a wealth of experience indicates that effective containment is technically and operationally feasible [15]. Phase 1a containment activities, have been achieved in Nigeria and ended with the destruction of all potentially infectious materials and type 2 poliovirus in all identified facilities. Laboratory staff capacity was strengthened, and the destruction process became systematic especially after the tOPV2-bOPV2 switch. This process is dynamics and needs meticulous monitoring to mitigate the risk of poliovirus leaving the laboratory back into the population. With few exceptions, the most extensive collections of potentially infectious materials are located in the research laboratories of a small number of developed and developing countries [16] with implications for a continuous survey and destruction of these materials. We recommend the regular capacity building of laboratory personnel on polio laboratory containment coupled with regular NTF visits to ensure strict adherence to Global Action Plan requirements as Nigeria prepares for polio-free status in a few years to come as well as the entire Africa region.

\section{Abbreviations}

AFP: Acute Flaccid Paralysis; ARCC: Africa Regional Commission for the Certification of Poliomyelitis Eradication; bOPV2: Bivalent oral polio vaccine type 2; BSL-2: Biosafety Level 2; ES: Environmental Surveillance; GAPIII: Global Action Plan III; GCC: Global Commission for the Certification of poliomyelitis eradication; MS: Microsoft; NCDC: Nigeria Centre for Disease Control; NTF: National Task Force for poliovirus containment; SOP: Standard Operating Procedure; SPSS: Statistical Program for the Social Sciences; tOPV2: Trivalent oral polio vaccine type 2; USA: United States of America; VDPV2: Vaccine Derived Poliovirus type 2; WHO: World Health Organization; WPV: Wild Polio Virus; WPV1: Wild Polio Virus type 1

\section{Acknowledgements}

We thank all members of the National Polio Certification Committee including the zonal consultants that were engaged in this exercise as well as both government and $\mathrm{WHO}$ personnel for their contribution to the realization of this work and to the World Health Organization for providing the funds and technical leadership for the conduct of phase 1a activities in Nigeria.

We recommend the regular capacity building of laboratory personnel on polio laboratory containment coupled with regular NTF visits to ensure strict adherence to Global Action Plan requirements as Nigeria prepares for polio-free status in a few years to come as well as the entire Africa region.

\section{Funding}

This work was supported by funds provided by the World Health Organization. Publication of this article will be sponsored by the polio eradication funds from the World Health Organization.

\section{Availability of data and materials}

The datasets used and/or analyzed during the current study are available from the corresponding author on reasonable request.

\section{About this supplement}

This article has been published as part of BMC Public Health Volume 18 Supplement 4, 2018: Experiences and lessons learned in polio eradication in Nigeria. The full contents of the supplement are available online at https://bmcpublichealth.biomedcentral.com/articles/supplements/volume18-supplement-4.

\section{Authors' contributions}

JMT: Designed the study, data analysis and drafted the paper that was approved by authors. AWH: Participated in study design and data analysis. KOM: Supervised data collection and analysis and also major co-author to review the drafted paper. CC: Participated in administration of questionnaires. IA: Participated in administration of questionnaires. AO: Participated in administration of questionnaires. DE: Participated in administration of questionnaires. JO: Participated in administration of questionnaires. MB: Participated in administration of questionnaires. All other authors: BF, PM, PN, 
$\mathrm{ET}, \mathrm{KC}, \mathrm{EA}, \mathrm{OE}, \mathrm{FS}, \mathrm{AF}, \mathrm{JA}, \mathrm{UA}, \mathrm{MD}, \mathrm{GO}, \mathrm{HB}, \mathrm{NN}, \mathrm{MB}, \mathrm{GN}, \mathrm{RB}, \mathrm{SGT}, \mathrm{AO}, \mathrm{OD}, \mathrm{TO}$ and $\mathrm{RG}$ participated in the discussion and reading of the manuscript. All the authors have read and approved the final manuscript.

\section{Ethics approval and consent to participate}

The analysis for this work was mainly based on secondary data. This data is available at the WHO server and permission was given by WHO country office to use for the study. The questionnaires were administered by the authors. For this, Ethical approval was obtained from the Federal Ministry of Agriculture and Rural Development of Nigeria.

\section{Consent for publication}

Not applicable.

\section{Competing interests}

The authors declare that they have no competing interests.

\section{Publisher's Note}

Springer Nature remains neutral with regard to jurisdictional claims in published maps and institutional affiliations.

\section{Author details}

${ }^{1}$ World Health Organization, Country Representative Office, Abuja, Nigeria. ${ }^{2}$ World Health Organization, Regional Office for Africa, Brazzaville, Congo. ${ }^{3}$ National Primary Health Care Development Agency, Abuja, Nigeria. ${ }^{4}$ National Task Force on Polio Containment, Abuja, Nigeria. ${ }^{5}$ University Teaching Hospital Polio Laboratory, Maiduguri, Nigeria. ${ }^{6} \mathrm{Global}$ Public Health Solutions, Atlanta, GA, USA. 'World Health Organization, Headquarters, Geneva, Switzerland. ${ }^{8}$ Expert Review Committee on Polio and Routine Immunization, Abuja, Nigeria.

\section{Published: 13 December 2018}

\section{References}

1. Black CL, Yankey D, Kolasa M. Morbidity and Mortality Weekly Report National, State, and Local Area Vaccination Coverage Among Children Aged 19-35 Months - United States, 2012. Mmwr. 2013;62(36):733-40.

2. WHO. Polio Eradication \& Endgame Strategic Plan 2013-2018. 2013;

3. Global WHO, Plan A. Who/polio/15.05.

4. Geneva C. Sage Confirms Global Vaccine Switch Date As April 2016. 2016; 6736(11):18-21.

5. Fine PEM, Oblapenko G, Sutter RW. Polio control after certification: major issues outstanding. Bull World Health Organ. 2004;82(1):47-52.

6. Wolff C, Roesel S, Lipskaya G, Landaverde M, Humayun A, Withana N, et al. Progress toward laboratory containment of poliovirus after polio eradication. J Infect Dis. 2014;210(Suppl 1):S454-8.

7. Aylward RB, Cochi SL. Framework for evaluating the risks of paralytic poliomyelitis after global interruption of wild poliovirus transmission. Bull World Health Organ. 2004;82(1):40-6.

8. WHO. WHO global action plan for laboratory containment of wild polioviruses. World Health [Internet]; 2002. p. 49. Available from: http://www.who.int/vaccines-documents/DocsPDF03/www729.pdf. Accessed 10 Aug 2002

9. Paper O. Towards a Sustainable Wild Poliovirus Containment Strategy in Zambia. Med J Zambia. 2012;39(2):1-3.

10. Laboratory Containment of Wild Polio Viruses Survey and Inventory in Sudan.pdf.

11. Sneyers M, Ph H, Moens W. Polio eradiction and laboratory containment programme of wild polioviruses in Belgium . Laboratory survey and inventory phase. Arch of Public Health. 2005;63:57-65.

12. Johnson Muluh T, Hamisu AW, Craig K, Mkanda P, Andrew E, Adeniji J, et al. Contribution of environmental surveillance toward interruption of poliovirus transmission in Nigeria, 2012-2015. J infect dis [internet]. 2016;213:1-5 Available from: http://www.ncbi.nlm.nih.gov/pubmed/26908747. Accessed 20 Feb 2016.

13. Huang QS, Greening G, Baker MG, Grimwood K, Hewitt J, Hulston D, et al. Persistence of oral polio vaccine virus after its removal from the immunisation schedule in New Zealand. Lancet. 2005;366(9483):394-6.

14. Centers for Disease C, Prevention. National laboratory inventories for wild poliovirus containment--Western Pacific. region, 2008. MMWR Morb Mortal Wkly Rep. 2009;58:975-8.
15. Van Loon A. Can effective containment of wild polioviruses in laboratories and inactivated poliovirus vaccine production sites ever be achieved? Bull World Health Organ. 2004;82(03):63-4.

16. Dowdle WR, Gary HE, Sanders R, Loon AMV. Can post-eradication laboratory containment of wild polioviruses be achieved? Bull World Health Organ. 2002;80:311-6.

\section{Ready to submit your research? Choose BMC and benefit from:}

- fast, convenient online submission

- thorough peer review by experienced researchers in your field

- rapid publication on acceptance

- support for research data, including large and complex data types

- gold Open Access which fosters wider collaboration and increased citations

- maximum visibility for your research: over $100 \mathrm{M}$ website views per year

At BMC, research is always in progress.

Learn more biomedcentral.com/submission 